\title{
Methodology for designing lateral lines with microtubes operated under variable inlet pressure
}

\author{
Geancarlo T. Katsurayama ${ }^{1}$, Ezequiel Saretta ${ }^{2}$, Antonio P. de Camargo ${ }^{3}$, \\ Tarlei A. Botrel ${ }^{3}$ \& Conan A. Salvador ${ }^{4}$ \\ ${ }^{1}$ Instituto Federal de Educação, Ciência e Tecnologia Catarinense/Campus Araquari. Araquari, SC. E-mail: geancarlo.katsurayama@ifc.edu.br \\ (Corresponding author) \\ ${ }^{2}$ Universidade Federal de Santa Maria/Campus Cachoeira do Sul. Cachoeira do Sul, RS. E-mail: ezequiel.saretta@ufsm.br \\ ${ }^{3}$ Universidade de São Paulo/Escola Superior de Agricultura 'Luiz de Queiroz'. Piracicaba, SP. E-mail: acpires@usp.br; tabotrel@usp.br \\ ${ }^{4}$ Universidade Federal Rural do Rio de Janeiro/Departamento de Engenharia. Seropédica, RJ. E-mail: conanayade@yahoo.com.br
}

Key words:

micro-irrigation

alternative power sources

distribution uniformity

\begin{abstract}
A B S T R A C T
Design of lateral lines consisting of microtubes enables to optimize water distribution uniformity. In addition, there must exist a range of pressures at the lateral line inlet in which the water distribution uniformity remains acceptable. Thus, such emitters are interesting for use in micro-irrigation systems supplied by alternative power sources, in which temporal variability in the electrical power supplied to the pumping systems normally occurs. This study presents a methodology for designing lateral lines with microtubes operated under varying pressure, using the step-by-step method in order to establish the recommended range of lateral line inlet pressures. The proposed methodology was validated over three replicates by testing maximum, minimum and optimum pressures. Deviation between estimated and observed values of flow rate was lower than $6 \%$, indicating a satisfactory accuracy. Distribution uniformity of the system was higher than $95 \%$ under all pressures within the estimated range of values. Lateral lines can operate within a wide range of operating pressures and even so satisfactory results of distribution uniformity are obtained.
\end{abstract}

Palavras-chave:

microirrigação

energia alternativa

uniformidade de distribuição

\section{Metodologia para dimensionamento de linhas laterais com microtubos operadas sob pressão de entrada variável}

\begin{abstract}
R E S U M O
O dimensionamento de linhas laterais constituídas por microtubos de comprimento variável, permite a obtenção de uniformidade de distribuição de água otimizada. Supõe-se que existe um intervalo de pressões de entrada na linha lateral no qual a uniformidade de distribuição de água é mantida dentro de limites aceitáveis. Deste modo, esses emissores podem ser aplicados em sistemas de irrigação em que há variação temporal de potência para o bombeamento. Assim, este trabalho propõe uma metodologia para dimensionar linhas laterais constituídas por microtubos sob pressão variável utilizando o método trecho a trecho a fim de se estabelecer o intervalo de pressões recomendadas para operação. A metodologia foi validada ensaiando-se a pressão máxima, ótima e mínima obtida, com três repetições. A diferença entre valores estimados e observados de vazão foi inferior a $6 \%$, indicando que o equacionamento adotado apresentou acurácia satisfatória. A uniformidade de distribuição do sistema foi superior a 95\% para todas as pressões ensaiadas; demonstrou-se, portanto, que é possível estabelecer um amplo intervalo de pressões de operação mantendo-se a uniformidade de distribuição dentro de limites aceitáveis.
\end{abstract}




\section{INTRODUCTION}

Microtubes are long-distance emitters whose length can be adjusted according to the distribution of pressures along the lateral line (Almeida et al., 2009), allowing optimized distribution uniformity. The flexibility for the configuration of each microtube in lateral lines becomes interesting for use in irrigation systems operated with alternative power sources, such as solar or aeolian. These power sources have temporal variability in the electric power supplied to motor pump set, and it is common to use power accumulators, tanks, pressurecompensating emitters (Pande et al., 2003) and/or pressureregulating valves, for the flow rate to remain stable during the irrigation events. However, these devices exhibit losses that could be reduced in case of direct attachment between the irrigation system and the motor pump set; for that, it is convenient that the irrigation systems accept certain variations of power.

Studies on the uniformity of irrigation systems operated under different pressures (Chigerwe et al., 2004; Almeida et al., 2006; Sah et al., 2010; Klein et al., 2013) and on the use of alternative power sources directly attached to the irrigation systems are available in the literature (López-Luque et al., 2015; Reca et al., 2016). However, little is known about the range of inlet pressures that guarantees adequate distribution uniformity. It is imagined that, in the utilization of microtube emitters, there is a range of inlet pressures in the line, around an optimal value that allows operation with proper distribution uniformity and, therefore, it is admissible that there are variations in the inlet pressure of lateral lines.

Thus, the objective of this study was to develop a methodology for the dimensioning of lateral lines with microtubes operated under variable inlet pressure, determining the limits according to the environmental conditions.

\section{Material AND Methods}

\section{Methodology of dimensioning}

The methodology proposed for the dimensioning of lateral lines, consisting of microtube emitters operated under variable inlet pressure, is characterized by the steps described hereinafter. For microtube length and diameter, defined according to characteristics of the project or availability of material, one must calculate the pressure necessary at the inlet of the last emitter of the lateral line to obtain a pre-defined flow rate (Eq. 1). The Eq. 1, adapted from Souza \& Botrel (2004), is valid for microtubes operating in the laminar flow regime and contains terms that allow to quantify the head loss distributed along the microtube, the local loss resulting from the narrowing of the flow lines at the microtube inlet hole, the kinetic head on the discharge end of the microtube and the vertical distance between the microtube discharge hole and the lateral line.

$$
H=\frac{64}{R N} \frac{L}{D} \frac{v^{2}}{2 g}+k \frac{v^{2}}{2 g}+\frac{v^{2}}{2 g} \pm Z
$$

where:
$\mathrm{H}$ - head at the microtube inlet;
RN - Reynolds number, dimensionless;

L - microtube length, m;

$\mathrm{v} \quad$ - mean water flow velocity in the microtube, $\mathrm{m} \mathrm{s}^{-1}$;

D - microtube internal diameter, $\mathrm{m}$;

g - gravity acceleration, $\mathrm{m} \mathrm{s}^{-2}$;

$\mathrm{k}$ - local head loss coefficient, dimensionless; and,

$\mathrm{Z}$ - gradient between the microtube discharge hole and the lateral line, $\mathrm{m}$.

Once the required head at the last emitter of the lateral line is determined, the lateral line is dimensioned through the step-by-step method, with calculation from the last emitter (Yildirim, 2010). The procedure consists in the calculation of the pressure at the emitter $\mathrm{i}-1$ considering the pressure at the emitter $i$, the losses distributed in the segment between both emitters considered and the local head losses at the emitter i-1 (Eq. 2). The index i represents the emitter closest to the end of the lateral line, while i- 1 indicates the emitter immediately after the emitter i. Once the pressure at i- 1 is determined by Eq. 2, the microtube length at i- 1 is determined by Eq. 1 . The procedure is repeated until all microtubes of the lateral line are dimensioned.

$$
\mathrm{H}_{\mathrm{i}-1}=\mathrm{H}_{\mathrm{i}}+\mathrm{hf}_{\mathrm{D}_{\mathrm{i} \rightarrow(\mathrm{i}-1)}}+\mathrm{hf}_{\mathrm{L}_{(\mathrm{i}-1)}}
$$

where:

$\mathrm{H}_{\mathrm{i}-1}$ - head at emitter i-1, m;

$\mathrm{H}_{\mathrm{i}} \quad$ - head at emitter i, m;

$h f_{D i \rightarrow(i-1)}$ - head loss distributed along the segment between both emitters in question, $\mathrm{m}$; and,

$\mathrm{hf}_{\mathrm{L}(\mathrm{i}-1)}$ - local head loss in the lateral line due to the insertion of the emitter i-1, m.

After dimensioning the length of all microtubes, the inlet pressure of the line $\left(\mathrm{H}_{0}\right)$ is calculated, which results from the sum of the pressure in the first emitter with the total head loss in the segment between this emitter and the beginning of the line. The obtained value represents the optimal pressure $\left(\mathrm{P}_{\mathrm{opt}}\right)$ because, theoretically, it provides a flow rate variation $\left(\mathrm{Q}_{\mathrm{var}}\right)$ of $0 \%$ (Eq. 3).

$$
\mathrm{Q}_{\mathrm{var}}=100 \frac{\left(\mathrm{Q}_{\max }-\mathrm{Q}_{\min }\right)}{\mathrm{Q}_{\max }}
$$

where:

$\mathrm{Q}_{\text {var }}$ - flow rate variation, \%;

$\mathrm{Q}_{\max }$ - highest flow rate, $\mathrm{L} \mathrm{h}^{-1}$; and,

$\mathrm{Q}_{\min }$ - lowest flow rate, $\mathrm{L} \mathrm{h}^{-1}$.

Subsequently, the admissible range of inlet pressures is determined, in which the distribution uniformity of the lateral line remains within acceptable limits of the order of 10 to $20 \%$ (Frizonne et al., 2012). After defining the flow rate variation accepted in the already dimensioned lateral line, the admissible range of pressures is calculated through iterations. The maximum pressure $\left(\mathrm{P}_{\max }\right)$ at the inlet of the lateral line is obtained through increments in the pressure of the last emitter, recalculating the pressure and flow rate profiles and then the value of $\mathrm{Q}_{\mathrm{var}}$ in the lateral line. The maximum 
admissible pressure is that resulting in $\mathrm{Q}_{\mathrm{var}}$ close to the value pre-established as criterion for hydraulic dimensioning of the lateral line. Similarly, the minimum pressure $\left(\mathrm{P}_{\min }\right)$ at the inlet of the lateral line is obtained through iterations, decreasing the pressure of the last emitter until reaching $\mathrm{Q}_{\mathrm{var}}$ close to the pre-defined value.

\section{Demonstration of use of the methodology}

To demonstrate the proposed methodology, the following conditions were established for the dimensioning of one lateral line, which was projected and installed at the field: a) level lateral line, constituted by a polyethylene pipe with internal diameter of $12.7 \mathrm{~mm}$; b) vertical distance of $13 \mathrm{~cm}$ between the lateral line and the microtube discharge hole; c) line with 240 microtubes spaced by $10 \mathrm{~cm}$, which should have flow rate of $1.0 \mathrm{~L} \mathrm{~h}^{-1}$ when operated at the optimal pressure $\left.(31.97 \mathrm{kPa}) ; \mathrm{d}\right)$ microtubes with internal diameter of $0.739 \mathrm{~mm}$; e) local head loss coefficient due to the narrowing of the flow lines at the microtube inlet hole ( $\mathrm{k}$ ) equal to 17.78 ; f) local head loss in the lateral line due to the insertion of the microtube estimated by $\mathrm{hf}_{\mathrm{l}}=0.01239 \mathrm{v}^{1.543}$, for the laminar flow regime; and by $\mathrm{hf}_{\mathrm{l}}$ $=0.00660 \mathrm{v}^{1.679}$, for the other flow regimes; g) admissible flow rate variation in the lateral line $\left(\mathrm{Q}_{\mathrm{var}}\right)$ defined as $7 \%$; $\mathrm{h}$ ) water temperature of $25^{\circ} \mathrm{C}$; i) increments of $9.81 \mathrm{~Pa}$ in the iterative calculations for the determination of $\mathrm{P}_{\min }$ and $\mathrm{P}_{\max }$.

In segments of the lateral line with laminar flow regime $(\mathrm{RN}$ $<2000$ ), the friction factor (f) of the Darcy-Weisbach equation was calculated using Eq. 4 . For the rest of the flow conditions ( $R N \geq 2000)$, Eq. 5 was used and its coefficients were adjusted to polyethylene pipes with small diameter (Cardoso et al., 2008).

$$
\begin{gathered}
f=\frac{64}{R N} \\
f=\frac{0.3}{R^{0.25}}
\end{gathered}
$$

where:

$\mathrm{RN}$ - Reynolds number, dimensionless.

\section{Indicators of uniformity in the lateral line}

The previously dimensioned line was evaluated at the field in 2014, operating under optimal pressure and at the calculated upper and lower limits. For that, the flow rates of 51 emitters were measured along the line and compared with the estimated results. The flow rate was determined based on the mass of water collected in a time sufficient to collect approximately 400 to $500 \mathrm{~g}$. Three replicates were performed for the three pre-determined pressures for water temperature in the test, which was $20^{\circ} \mathrm{C}$. Water temperature was used to determine the specific weight of water through the equation suggested by Kell (1975) (Eq. 6).

$$
\rho=\frac{\left(\begin{array}{l}
999.8676+17.801161 \mathrm{~T}- \\
7.942501 \times 10^{-3} \mathrm{~T}^{2}-52.56328 \times 10^{-6} \mathrm{~T}^{3}+ \\
137.6891 \times 10^{-9} \mathrm{~T}^{4}-364.4647 \times 10^{-12} \mathrm{~T}^{5}
\end{array}\right)}{\left(1+17.735441 \times 10^{-3} \mathrm{~T}\right)}
$$

where:

$$
\begin{aligned}
& \rho \text { - specific weight of water, } \mathrm{kg} \mathrm{m}^{-3} \text {; and, } \\
& \mathrm{T} \text { - temperature, }{ }^{\circ} \mathrm{C} \text {. }
\end{aligned}
$$

Values observed at the field and mathematically estimated were compared through the relative difference of flow rate (Eq. 7), obtained for each emitter evaluated, at each pressure.

$$
\Delta \mathrm{Q}=100\left(\frac{\left|\overline{\mathrm{q}_{\mathrm{o}}}-\overline{\mathrm{q}_{\mathrm{e}}}\right|}{\overline{\mathrm{q}_{\mathrm{o}}}}\right)
$$

where:

$\Delta \mathrm{Q}$ - relative difference, $\%$;

$\overline{\mathrm{q}_{\mathrm{o}}} \quad$ - mean flow rate observed, $\mathrm{L} \mathrm{h}^{-1}$; and,

$\overline{\mathrm{q}_{\mathrm{e}}}$ - mean flow rate estimated, $\mathrm{L} \mathrm{h}^{-1}$.

Distribution uniformity was expressed through the statistical uniformity coefficient (SUC) and distribution uniformity of the lowest quartile (DU).

Lastly, due to the sensitivity of the microtube flow rate to water temperature, especially for laminar flow regime, $\mathrm{P}_{\text {opt' }}$, $\mathrm{P}_{\text {max }}$ and $\mathrm{P}_{\text {min }}$ were calculated for the temperatures of 10,15 , $20,25,30$ and $35^{\circ} \mathrm{C}$, where $\mathrm{P}_{\text {opt }}$ is the pressure that would lead to the lowest $\mathrm{Q}_{\text {var }}$.

\section{Results AND Discussion}

As shown in Figure 1A, the length of the microtubes installed in the lateral line used as example decreased from the first to the last emitter, since the pressure decreased along the line due to the head loss. Thus, the first emitters are longer, to dissipate more pressure at the beginning of the lateral line and, consequently, provide the pre-established flow rate. Although the flow rate was maintained constant along the lateral line, the dimensioning requires each microtube to have individualized length (Figure 1A).

Regarding the inlet pressure of the projected lateral line, the optimal value $\left(\mathrm{P}_{\text {opt }}\right)$ was $31.97 \mathrm{kPa}$, whose pressure at the end of the line was $26.15 \mathrm{kPa}$ (Figure $1 \mathrm{~B}$ ), leading to a $\mathrm{Q}_{\text {var }}$ equal to 0 , despite a pressure variation of approximately $18 \%$. In the case of emitters with flow exponent equal to 0.5 , this same pressure variation would lead to $\mathrm{Q}_{\mathrm{var}}$ of approximately $10 \%$, indicating that, despite the labor required to build the lateral lines, in systems with variable pressure the use of microtubes has, as advantage over emitters with turbulent flow, the generation of longer lateral lines with no losses in terms of flow rate variation or distribution uniformity.

Respecting the maximum flow rate variation of $7 \%$ between the first and last emitters of the lateral line, the inlet pressures can vary between $13.28 \mathrm{kPa}\left(\mathrm{P}_{\min }\right)$ and $68.64 \mathrm{kPa}\left(\mathrm{P}_{\max }\right)$. Hence, it is possible to alter the inlet flow rate to values within this interval, promoting flexibility in the operation of the lateral lines and maintaining the flow rate variation within the stipulated limit.

Due to the alteration in microtube flow rate because of water temperature, the pressure limits must be corrected. Figure 2 presents these relationships, as well as the intervals 

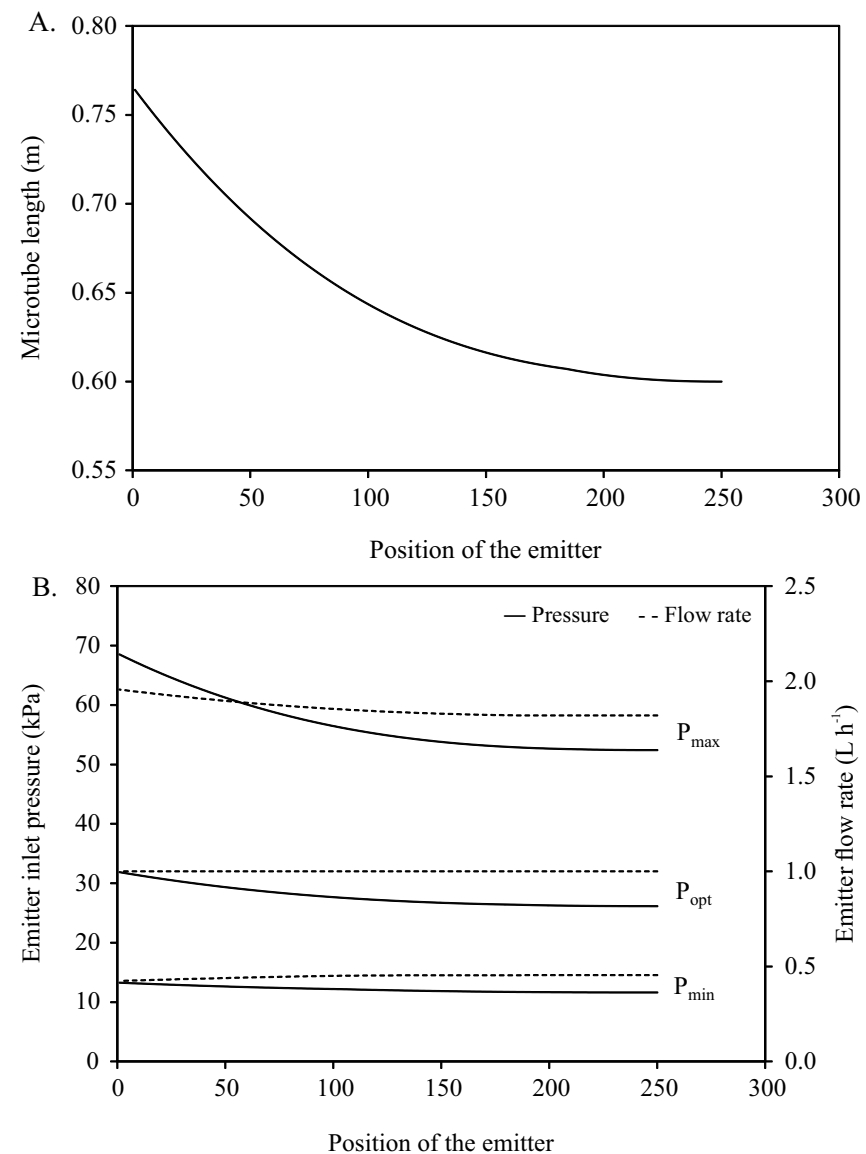

Figure 1. Variation of microtube length along the projected lateral line (A); Profiles of minimum, optimal and maximum pressures along the projected lateral line (B) considering water temperature of $25^{\circ} \mathrm{C}$

recommended for the operation of the lines, according to the water temperature (from 10 to $35^{\circ} \mathrm{C}$ ). The values of inlet pressure (Figure 2A) and mean flow rate of the emitters (Figure $2 \mathrm{~B}$ ) were also obtained respecting the criterion of $7 \%$ of flow rate variation along the lateral line. As water temperature decreased, the range of inlet pressure increased, allowing greater flexibility for operation. While for the temperature of $10^{\circ} \mathrm{C}, \mathrm{P}_{\text {min }}$ was $29.02 \mathrm{kPa}$ and $\mathrm{P}_{\text {max }}$ was $150.48 \mathrm{kPa}$, for the temperature of $35^{\circ} \mathrm{C}, \mathrm{P}_{\text {min }}$ and $\mathrm{P}_{\text {max }}$ were equal to 8.24 and 43.06 $\mathrm{kPa}$, respectively. Thus, for each one of these temperatures there may be a modification of more than five times in the inlet pressure of the line and, despite that, the distribution uniformity is maintained within acceptable limits. In addition, since the variation in water temperature leads to variation of inlet pressure in the line, there is also a change in the flow rate of the emitters (Figure 2B).

The water temperature for which the field test was conducted was $20{ }^{\circ} \mathrm{C}$, requiring the calculation of the
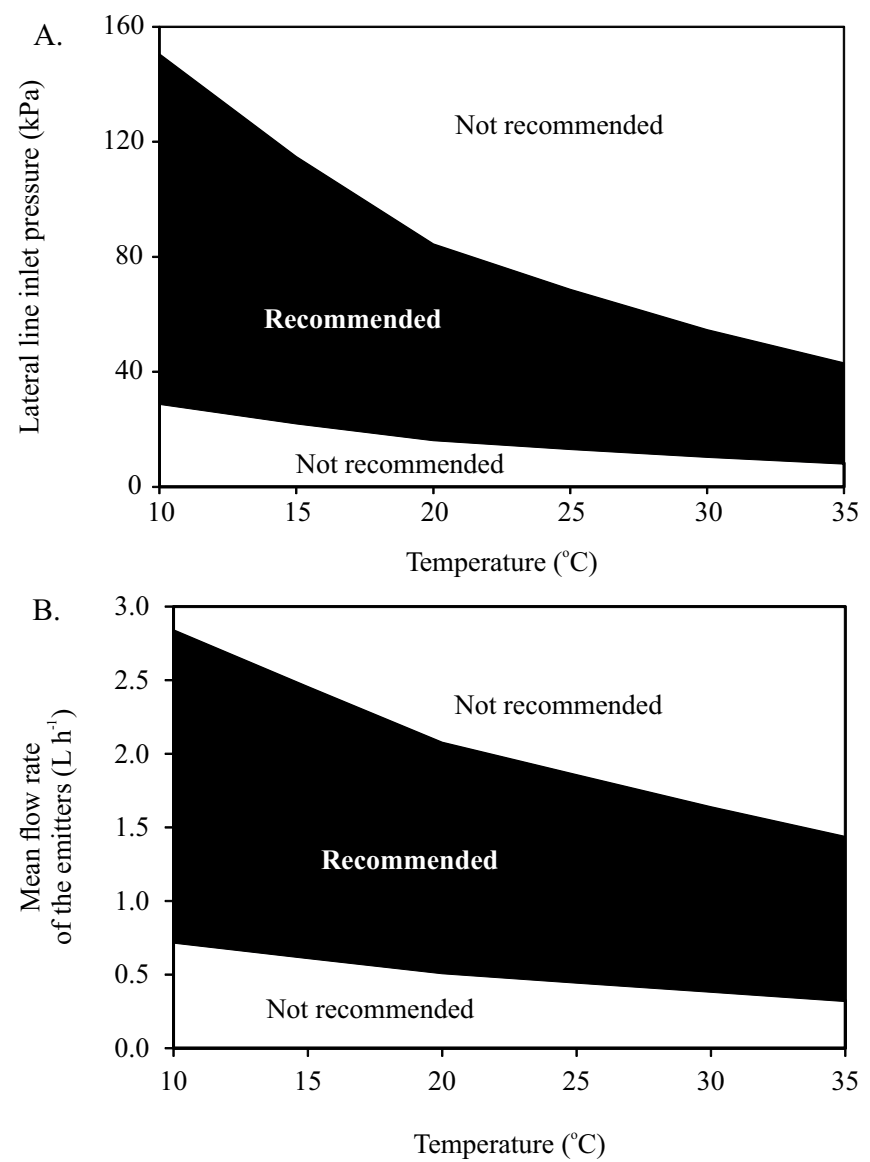

Figure 2. Effect of water temperature on the acceptable limits of lateral line inlet pressure $(A)$ and on the mean flow rate of the microtube emitters $(B)$

corresponding pressures. The results of this analysis are presented in Table 1.

Both indices, DU and SUC, reported excellent uniformity according to Bralts (1986), since they were all above 90\%. These results of uniformity, along with the values of relative difference of flow rate, indicate that the dimensioning of the range of pressures was valid under the conditions of the experiment and for the established criteria. Also testing different operating pressures in microtube kits, Sah et al. (2010) obtained DU values above $90 \%$ and SUC higher than $85 \%$, both for the conditions of level and non-level line. The obtained results of SUC are consistent with those of Souza et al. (2011), who also obtained excellent values (98.25\%) using microtubes with variable lengths in fertigation. This indicates that microtubes with different lengths along the line have more advantage over those with a single length, although Souza et al. (2006) report DU values of 96.9\% for microtubes with fixed length. In evaluations of kits of lines with fixed-length microtubes, Chigerwe et al. (2004) also varied the inlet pressure, but the mean values of DU were lower

Table 1. Information on the operation of the lateral line, relative differences of flow rates and indicators of distribution uniformity for the three tested pressures

\begin{tabular}{|c|c|c|c|c|c|c|}
\hline \multirow{3}{*}{ Pressure } & \multirow{3}{*}{$\begin{array}{l}\text { Pressure } \\
\text { (kPa) }\end{array}$} & \multicolumn{2}{|c|}{ Mean flow rate of the emitters $\left(L h^{-1}\right)$} & \multirow{2}{*}{$\begin{array}{c}\text { Relative difference between } \\
\text { estimated and observed flow rates }\end{array}$} & \multirow{2}{*}{$\mathbf{D U}^{*}$} & \multirow{2}{*}{ SUC $^{*}$} \\
\hline & & & Ohserved & & & \\
\hline & & Estiniateu & Udserveu & \multicolumn{3}{|l|}{$(\%)$} \\
\hline$P_{\min }$ & 16.32 & 0.51 & 0.50 & 1.77 & 95.25 & 96.79 \\
\hline $\mathrm{P}_{\mathrm{opt}}$ & 39.00 & 1.12 & 1.11 & 0.56 & 97.80 & 98.37 \\
\hline$P_{\max }$ & 84.43 & 2.08 & 2.06 & 1.12 & 97.93 & 98.37 \\
\hline
\end{tabular}

${ }^{*}$ DU - Distribution uniformity of the lowest quartile; SUC - Statistical uniformity coefficient 
than $90 \%$ in three of the four kits. Souza et al. (2009) evaluated similar kits and obtained DU values lower than $70 \%$ in some of them, which can be considered as bad (Bralts, 1986), agreeing that the utilization of emitters with the same length was one of the factors for the lower uniformity.

The first emitters showed greater differences between estimated and observed flow rate (Figure 3A). Anyway, the highest value of $\Delta \mathrm{Q}$ obtained was approximately $6 \%$, for $\mathrm{P}_{\max }$, which indicates that the hydraulic estimates were sufficiently accurate and adequately represent the evaluated system.

According to Figure $3 \mathrm{~B}$, approximately $90 \%$ of the $\Delta \mathrm{Q}$ values (Eq. 7) were lower than 3\%. For that, the strategy of compensating the flow rate along the line by modifying the length of the microtubes was validated with the experimental data; therefore, electrical energy sources with variable power supply can be used provided that the irrigation system operates within the admissible range of pressures calculated according to the described methodology. Hence, uniformity indices will be maintained adequate, even when the irrigation system operates under variable pressure.
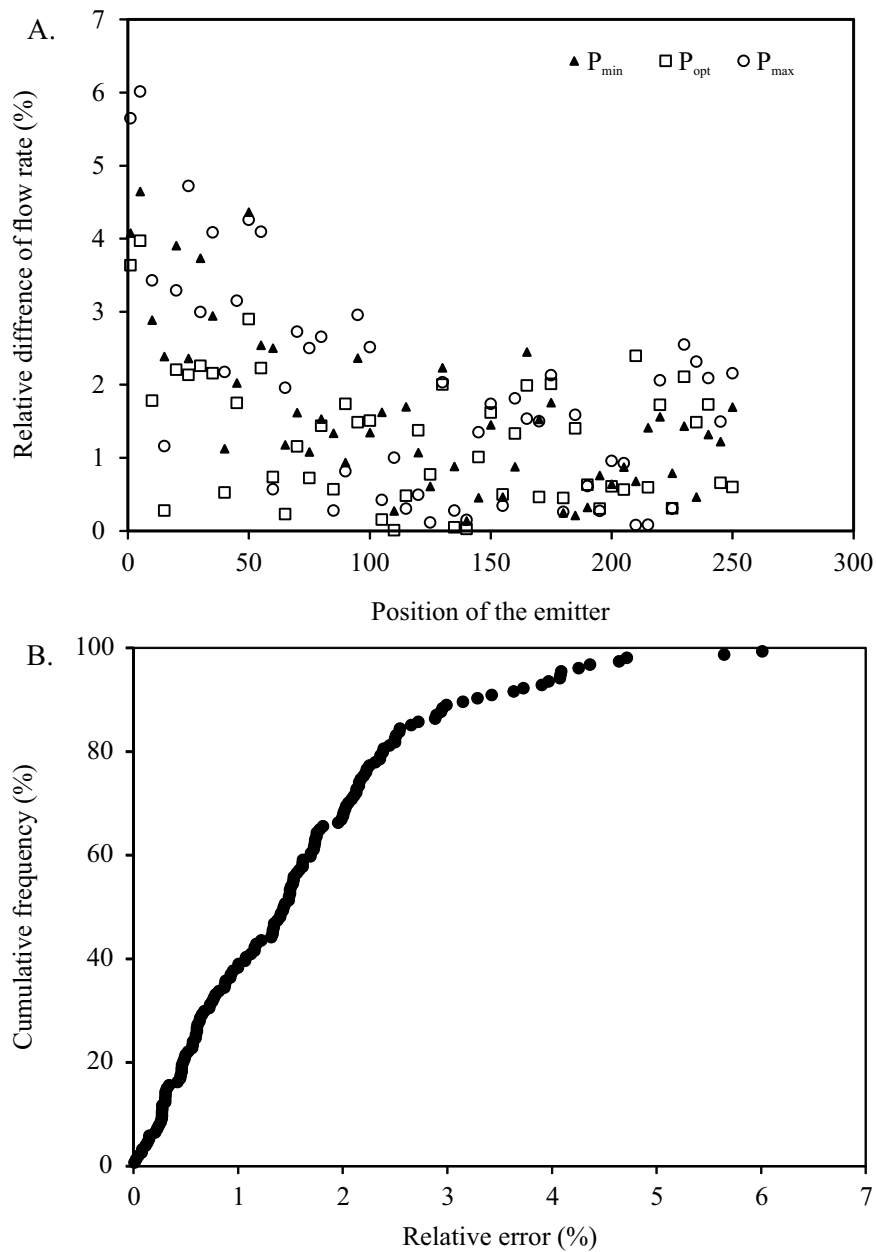

Figure 3. Relative differences of flow rate in the emitters for the maximum $\left(\mathrm{P}_{\max }\right)$, optimal $\left(\mathrm{P}_{\text {opt }}\right)$ and minimum pressure $\left(\mathrm{P}_{\min }\right)(\mathrm{A})$; cumulative frequency of the errors between observed and estimated values (B)

\section{Conchusions}

1. The utilized methodology allows to dimension lateral lines constituted by microtubes with variable length.
2. The utilized methodology allows to determine the range of operating pressures that guarantees adequate distribution uniformity.

3. The deviations between flow rate values observed at the field and estimated were lower than $6 \%$, indicating adequate accuracy of the equating adopted in the dimensioning.

4. Water temperature has significant influence on the recommended range of operating pressures of lateral lines that use microtube emitters.

\section{ACKNOWLedgments}

To the Ministry of Science and Technology (MCT), National Council for Scientific and Technological Development (CNPq), São Paulo State Research Support Foundation (FAPESP), for the financial support, through the National Institute of Science and Technology in Irrigation Engineering (INCTEI).

\section{Literature Cited}

Almeida, A. M.; Sampaio, S. C.; Suszek, M. Comportamento hidráulico de gotejadores em linha lateral de irrigação. Varia Scientia, v.6, p.129-140, 2006.

Almeida, C. D. G. C. de; Botrel, T. A.; Smith, R. J. Characterization of the microtube emitters used in a novel micro-sprinkler. Irrigation Science, v.27, p.209-214, 2009. https://doi.org/10.1007/s00271-008-0135-y

Bralts, V. F. Field performance and evaluation. In: Nakayama, F. S.; Bucks, D. A. (ed.). Trickle irrigation for crop production. Amsterdam: Elsevier, 1986. Chap.3, p.216-240. https://doi. org/10.1016/B978-0-444-42615-4.50014-X

Cardoso, G. G. G.; Frizzone, J. A.; Rezende, R. Fator de atrito em tubos de polietileno de pequenos diâmetros. Acta Scientiarum Agronomy, v.30, p.299-305, 2008.

Chigerwe, J.; Manjengwa, N.; Zaag, P. van der; Zhakata, W.; Rockström, J. Low head drip irrigation kits and treadle pumps for smallholder farmers in Zimbabwe: A technical evaluation based on laboratory tests. Physics and Chemistry of the Earth, v.29, p.1049-1059, 2004. https://doi.org/10.1016/j.pce.2004.08.007

Frizzone, J. A.; Freitas, P. S. L.; Rezende, R.; Faria, M. A. Microirrigação: Gotejamento e microaspersão. Maringá: EDUEM, 2012. 356p.

Kell, G. S. Density, thermal expansivity, and compressibility of liquid water from $0^{\circ}$ to $150^{\circ} \mathrm{C}$ : Correlations and tables for atmospheric pressure and saturation reviewed and expressed on 1968 temperature scale. Journal of Chemical Engineering Data, v.20, p.97-105, 1975. https://doi.org/10.1021/je60064a005

Klein, M.; Szekut, F.; Suszek, F.; Reis, C.; Aymoré, C.; Guerra, J.; Vilas Boas, M. Uniformidade de irrigação e fertigação em um sistema de irrigação familiar por gotejamento sob diferentes cargas hidráulicas. Engenharia Ambiental, v.10, p.56-69, 2013.

López-Luque, R.; Reca, J.; Martínez, J. Optimal design of a standalone direct pumping photovoltaic system for deficit irrigation of olive orchards. Applied Energy, v.149, p.13-23, 2015. https://doi. org/10.1016/j.apenergy.2015.03.107

Pande, P. C.; Singh, A. K.; Ansari, S.; Vyas, S. K.; Dave, B. K. Design development and testing of a solar PV pump based drip system for orchards. Renewable Energy, v.28, p.385-396, 2003. https:// doi.org/10.1016/S0960-1481(02)00037-X

Reca, J.; Torrente, C.; López-Luque, R.; Martínez, J. Feasibility analysis of a standalone direct pumping photovoltaic system for irrigation in Mediterranean greenhouses. Renewable Energy, v.85, p.11431154, 2016. https://doi.org/10.1016/j.renene.2015.07.056 
Sah, D. N.; Purohit, R. C.; Kumar, V.; Shukla, A. K.; Jain, S. K. Design, construction and evaluation of low pressure and low cost drip irrigation system. International Agricultural Engineering Journal, v.19, p.32-38, 2010.

Souza, R. O. R. de M.; Botrel, T. A. Modelagem para o dimensionamento de microtubos em irrigação localizada. Revista Brasileira de Engenharia Agrícola e Ambiental, v.8, p.16-22, 2004. https://doi. org/10.1590/S1415-43662004000100003

Souza, R. O. R. de M.; Miranda, E. P.; Nascimento Neto, J. R. do; Ferreira, T. T. S.; Mesquita, F. P. Irrigação localizada por gravidade em comunidades agrícolas do Ceará. Revista Ciência Agronômica, v.40, p.34-40, 2009.
Souza, R. O. R. de M.; Pérez, G. F. E.; Botrel, T. A. Irrigação localizada por gravidade com microtubos. Irriga, v.11, p.266-279, 2006.

Souza, W. J.; Botrel, T. A.; Carvalho, D. F. de; Silva, L. D. B. da. Fertigação em mudas de citros utilizando-se mangueiras e microtubos sob regime de escoamento turbulento. Revista Brasileira Engenharia Agrícola e Ambiental, v.15, p.816-822, 2011. https://doi.org/10.1590/S1415-43662011000800008

Yildirim, G. Total energy loss assessment for trickle lateral lines equipped with integrated in-line and on-line emitters. Irrigation Science, v.28, p.341-352, 2010. https://doi.org/10.1007/s00271009-0197-5 